\title{
Removal of Polycyclic Aromatic Hydrocarbons from Pol- luted Water Using Constructed Wetlands: A Review
}

\author{
Mini Review
}

Volume 3 Issue 1- 2022

\begin{abstract}
Author Details
Erietta Chamalidou ${ }^{1}$, Alexandros Gazis ${ }^{2 *}$ and Georgios D Gikas ${ }^{1}$

${ }^{1}$ Department of Environmental Engineering, Democritus University of Thrace, Greece

${ }^{2}$ Department of Electrical and Computer Engineering, Democritus University of Thrace, Greece
\end{abstract}

*Corresponding author

Alexandros Gazis, Programming and Information Processing Laboratory, Department of Electrical and Computer Engineering Democritus University of Thrace, Greece

Article History

Received: December 26, 2021 Accepted: January 10, 2022 Published: January 11, 2022

\begin{abstract}
During the last decades, Polycyclic Aromatic Hydrocarbons (PAHs) are detected in agricultural soils and water bodies at concentrations higher than permitted limits. The main sources of PAHs are fossil fuels, biomass burning, waste incineration, and pesticides. They harm aquatic ecosystems and organisms and pose a high risk to human health. For these reasons, several laws have been enacted to regulate the permitted concentration levels of PAHs in the environment and specifically, the wastewater discharged into aquatic ecosystems. Several methods for the removal of PAHs from wastewater exist which, although efficient, are not used extensively due to their high installation and operation cost. Constructed Wetlands (CWs) constitute an effective, practical, and low-cost option for PAHs removal from polluted waters. This paper focuses on the various treatment processes for the removal of PAHs. Research findings indicated that vertical flow CWs and hybrid systems are more effective in removing PAHs.
\end{abstract}

Keywords: PAHs; Constructed wetlands; Wastewater; Naphthalene; Anthracene; Phenanthrene; Benzo[a]anthracene; Tetracene; Chrysenium, Benzo[a]pyrene

\section{Introduction}

During the last decades, environmental pollution and especially the atmosphere's contamination had a serious impact on increasing common environmental problems such as water and soil pollution. Analytically, we define water pollution as any form of unwanted changes in the physical, chemical, and biological characteristics of water. The main sources of this type of pollution are the point sources and non-point sources (or diffuse pollution).

Irrespective of the lakes' and rivers' size, we mark that pollutants could exist, caused by various human activities which are constantly increasing. One of the most dangerous pollutants for all living beings is Polycyclic Aromatic Hydrocarbons (PAHs).

PAHs have been studied extensively in recent bibliography where many researchers focus their works on water systems and current installations. Specifically, a property of great concern is the PAHs concentration values that tend to exceed the limits set by the European Union (EU) legislation and the individual countries alike [1]. PAHs have been detected at concentrations of up to $1.2 \mu \mathrm{g} / \mathrm{L}$ and $2.16 \mu \mathrm{g} / \mathrm{L}$ in Raba river, Hungary [2] and in Svratka river, Czech Republic [3], respectively. The PAHs anthracene and fluoranthene have also been measured at concentrations $0.17 \mu \mathrm{g} / \mathrm{L}$ and $0.93 \mu \mathrm{g} / \mathrm{L}$, respectively, in Nestos river N. Greece [4]. A two-year study performed by Witt [5] at the Baltic Sea, found out that the concentration values of PAHs in water were abnormal. Specifically, the results of this paper indicate that the levels of PAHs in the spring were significantly lower than those of the autumn. As shown by this study, the reason for this observation was attributed to the fact that in the autumn and winter, the temperature of the water is low, thus, the number of microorganisms is lower meaning that PAHs are not capable to oxidize by them. Moreover, it was observed that UV radiation during the autumn period was not sufficient for photooxidation. As a result, the percentage levels of PAHs in the fall ranged from $0.001 \mathrm{ng} / \mathrm{L}$ to $4.8 \mathrm{ng} / \mathrm{L}$. Furthermore, the PAHs of the two and three benzene rings 
were at higher concentrations than the PAHs of the six benzene rings, the average concentration of which was $0.1 \mathrm{ng} / \mathrm{L}$. Lastly, it was noticed that the concentration levels of PAHs with six benzene rings remained unchanged throughout the year as the natural degradation processes of PAHs were insufficient.

Schulz-Bull et al. [6] studied the PAHs detection levels in the North Atlantic Ocean around Iceland. PAHs of three to five benzene rings with concentrations above the permissible limit of $5 \mathrm{pg} / \mathrm{L}$ were measured. In particular, the concentration of PAHs ranged between 5 and $30 \mathrm{pg} / \mathrm{L}$ with phenanthrene and fluoranthene having the highest concentrations. In Colombia, the lack of environmental controls and legislation regarding water pollution has resulted in significant quantities of PAHs being released annually in water systems. To put things into perspective, in 2007, the local newspaper El Timepo published that about 500 tons of waste per day were discharged into the country's water systems [7]. Moreover, Sarria-Villa et al. [7] measured the concentration of PAHs in water and sediments at eight stations along the Cauca River. The PAHs measured in the most water samples were: fluorene, acenaphthylene, and anthracene, while in the sediments were: benzo[b]fluoranthene, benzo[k]fluoranthene, and pyrene. The PAHs concentrations levels in water ranged from 1.60 to $101.8 \mathrm{ng} / \mathrm{L}$ and in sediments from 0.4 to $26.5 \mu \mathrm{g} / \mathrm{kg}$. Due to the widespread presence of PAHs, it is important to further develop technologies for the treatment of water contaminated by them. For this purpose, several treatment technologies have been recommended such as chemical degradation, use of radioactivity and ultrasonic, advanced oxidation, biological degradation, and Constructed Wetlands (CWs) [8-10]. Among them, CWs are an efficient method with low operational and maintenance costs, and environmental impact.

This review aims at investigating the PAHs removal from wastewater and urban runoff, using CWs. For this, scientific literature was searched on Scopus, Science direct, Scholar Google, etc. Based on our findings, we have developed a database that includes the PAHS, the CW type as well as the design parameters of the CW such as dimensions, plant species, wastewater type, and the PAHs removal rate.

\section{PAHs- Definition}

PAHs are a class of pollutants derived from the incomplete combustion of petroleum products. Other sources of PAHs infection are the following [11]:

- Natural gas

- Burning of wood/forests

- Volcanic eruptions

- Waste incineration

- Pesticides

Furthermore, PAHs pollution derives from our everyday activities and our recent lifestyle. As such, some of the most common sources creating PAHs are the following [12]:

- Carbon-containing fuels: used for optimizing engines' operation (petrol engines etc.).

- Construction materials: regarding both traditional and contemporary industry processes.

- Household products: such as paints, finishes, coatings of crude oils, etc.

- Grilling food: as most grill machines run on coal.

\section{Constructed Wetlands}

CWs are natural systems that mimic the functions of natural wetlands (NW). Modern CWs have been designed and constructed for improved treatment capacity. The size and type of CWs, in addition to economic factors and budget restrictions, depend on various factors such as: the type of pollutants, the volume of wastewater, the meteorological conditions and the climate of the area, and the degree of wastewater treatment [13].

The basic types of CWs, in terms of the hydrological mode of operation, are the following $[14,15]$ :

- Free water surface (FWS) CW has areas of open water (Figure 1) while the water flows at the surface of the bed.

- Horizontal Subsurface Flow (HSF) CW, planted with wetland vegetation, and the water moves horizontally below the surface of the porous media from the inlet to outlet (Figure 2).

- Vertical Flow (VF) CW, designed to have vertical water flow. Similar to HSF they are planted and the water is treated as it percolates through the plant root zone (Figure 3).

CWs are the proposed solution for the treatment of various types of wastewaters such as: municipal, urban runoff, rainwater, agricultural wastewater, and industrial wastewater [16-20].

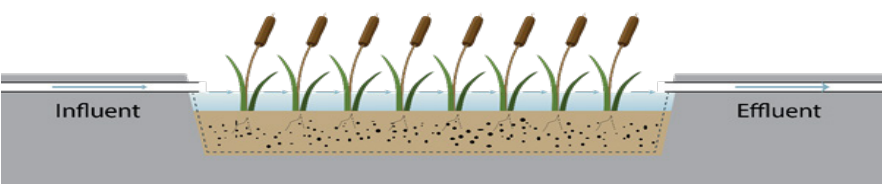

Figure 1: Free water surface CW.

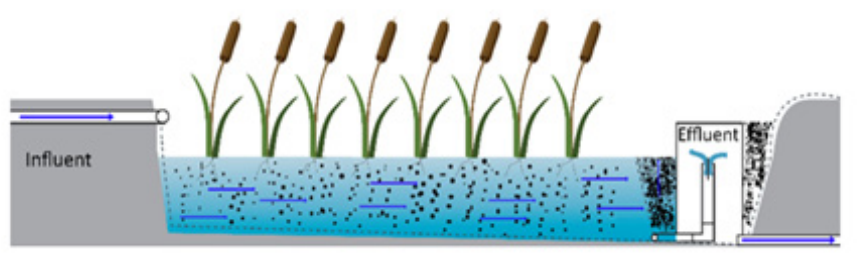

Figure 2: Horizontal subsurface flow CW.

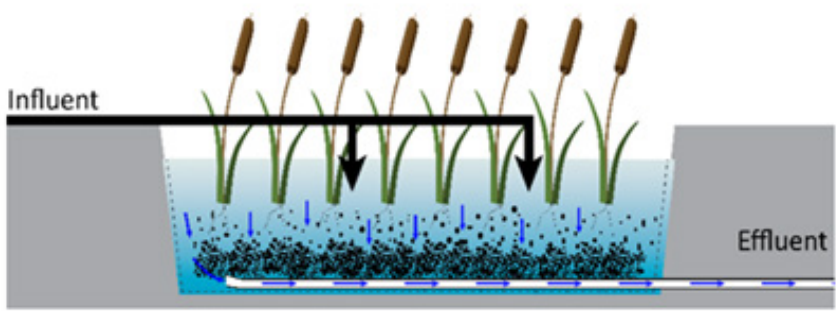

Figure 3: Vertical subsurface flow CW.

\section{Results}

Based on our study, after examining several articles on the use of CWs for the removal of PAHs from the wastewaters, a Database (DB) containing information on design parameters and performance of CWs was developed. Specifically, we indicatively present the use of constructed wetlands (Table 1) from our constructed DB, as well as data (Figure 5) regarding interesting publications in the field. As evident, our analysis gathered information on various properties, such as CW type, size, plant species, PAHs, wastewater type and removal rates.

(Figure 4) shows the removal rates of PAHs for different processes where the highest percentage of PAHs removal rates existed in the process regarding lab scale CW-MP. This type of CW is filled with freshwater mussels. The removal efficiency for five PAHs (i.e., $\mathrm{C}_{12} \mathrm{H}_{10}, \mathrm{C}_{12} \mathrm{H}_{8}, \mathrm{C}_{13} \mathrm{H}_{10}$, $\mathrm{C}_{16} \mathrm{H}_{10}, \mathrm{C}_{16} \mathrm{H}_{10}$ ) was equal to $97 \%$. The second highest percentage of PAHs removal occurred in processes of biological treatment in combination with (a) Ozone (Alto Seveso) as well as with (b) Peracetic acid (Nosedo) 
and the removal efficiency was equal to $96,5 \%$ and $89,5 \%$ respectively. Furthermore, the third highest percentage of PAHs removal exists in the process of the Hybrid (VF+HSF) system of CW. The removal efficiency was equal to $94 \%$. Also, the rest of the processes have a moderate efficiency of approximately $60-80 \%$ in the removal of PAHs. Lastly, as presented in (Figure 4), when CW is used in individual systems, the mean removal efficiency is about $70 \%$.

(Figure 5) presents box-whisker plots of the PAHs removal in FWS, HSF, VF, and Hybrid (VF+HSF) CWs. The line inside the box denotes median values, the upper box frame denotes the 75th percentile, the lower box frame denotes the 25th percentile, and the two whiskers denote the max and min values. Comparing the three CW types (i.e., FWS, HSF, and VF), higher PAHs mean removal was observed in VF CW. More specifically, the VF-CW showed better performance than HSF-CW and FWS-CW, and HSF-CW showed better performance than FWS-CW. The combination of VF and HSF-CWs (hybrid system) showed the highest PAHs removal.

(Figure 6) presents the performance of the technologies used to remove PAHs besides the CW. Analytically, the highest percentage rate of PAHs removal occurs in the photolysis and catalytic wet peroxide oxidation processes, as well as in all processes of photolysis (UV-C) whereas, the lowest effectiveness occurs in the methods of biological degradation.

Table 1: The use of constructed wetlands for PAHs removal.

\begin{tabular}{|c|c|c|c|c|c|c|}
\hline CW type & Size & Plant species & $\mathrm{PAHs}^{\mathrm{a}}$ & Wastewater & Removal (\%) & References \\
\hline HSF & $\begin{array}{c}20 \text { pilot scale systems } \\
\text { 90x30x50 (cm) }(\mathrm{L} \mathrm{x} \mathrm{W} \mathrm{x} \mathrm{H})\end{array}$ & Phragmites - Vetiver & (5), (11), (16) & Artificial & $66-83$ & [21] \\
\hline HSF & $45 \mathrm{~m}^{2}$ & $\begin{array}{l}\text { Phragmites australis and } \\
\text { Arudo donax }\end{array}$ & $(1)-(16)$ & Municipal & 79 & [22] \\
\hline FWS & $42 \mathrm{~m}^{2}$ & $\begin{array}{l}\text { Phragmites australis \& } \\
\text { Arudo donax }\end{array}$ & $(1)-(16)$ & Municipal & 68 & {$[22]$} \\
\hline FWS & $5 \mathrm{~m}^{2}$ & Unplanted & $(1)-(16)$ & Municipal & 73 & [22] \\
\hline FWS & $\begin{array}{l}2 \text { systems: } 11 \times 3 \times 0.4 \\
(\mathrm{~m})(\mathrm{L} \times \mathrm{W} \times \mathrm{H})\end{array}$ & $\begin{array}{c}\text { Arundo donax, } \\
\text { Phragmites australis }\end{array}$ & $(1)-(16)$ & Highway runoff & $\begin{array}{l}49-51 \\
58-57\end{array}$ & [23] \\
\hline HSF & $\begin{array}{l}2 \text { pilot scale systems: } 4 \times 8 \times 0.5 \\
(\mathrm{~m})(\mathrm{L} \times \mathrm{X} \times \mathrm{x})\end{array}$ & $\begin{array}{c}\text { Arundo donax, } \\
\text { Phragmites australis }\end{array}$ & $(1)-(16)$ & Highway runoff & $\begin{array}{l}59-47 \\
71-63\end{array}$ & [23] \\
\hline VF & $\begin{array}{l}14 \text { pilot scale systems: high } 70 \\
\mathrm{~cm} \text {, diameter } 25 \mathrm{~cm}\end{array}$ & Acorus calamus & (8) & Artificial & $83-99$ & [24] \\
\hline HSF & $\begin{array}{c}4 \text { pilot scale systems } \\
\text { 60x40x50 (cm) }(\mathrm{L} \times \mathrm{W} \times \mathrm{H})\end{array}$ & $\begin{array}{l}\text { Oenanthe javanica } \\
\text { (Blume) }\end{array}$ & (1), (2), (13), (16) & Municipal & $88-99$ & [25] \\
\hline FWS & - & & $\begin{array}{l}\text { (3), (5) - (8), (12), } \\
(14),(15)\end{array}$ & Municipal & $5-31$ & [26] \\
\hline VF & $\begin{array}{l}4 \text { pilot scale systems: high } 70 \\
\mathrm{~cm} \text {, diameter } 25 \mathrm{~cm}\end{array}$ & Iris pseudacorus & (11) & Municipal & $90-94$ & [27] \\
\hline VF & 3 pilot scale systems: $90 \mathrm{~m}^{2}$ & Phragmites australis & $\begin{array}{l}(1),(3)-(6),(9), \\
(11)-(13),(16)\end{array}$ & Municipal & $50-90$ & [28] \\
\hline VF & - & & $\begin{array}{l}(1),(4)-(7),(9), \\
(11)-(16)\end{array}$ & Municipal & $>80$ & [29] \\
\hline VF & - & Dianella revoluta & (11) & Municipal & 84 & [30] \\
\hline VF & $\begin{array}{c}4 \text { pilot scale systems: } \\
66 \times 25 \times 37(\mathrm{~cm})(\mathrm{L} \times \mathrm{W} \times \mathrm{H})\end{array}$ & $\begin{array}{c}\text { Acorus calamus, Canna } \\
\text { indica, Phragmites } \\
\text { australis }\end{array}$ & (5), (11), (16) & Municipal & $>99$ & [31] \\
\hline HSF & $\begin{array}{l}\text { Pilot scale: } 30 \times 30 \times 30(\mathrm{~cm})(\mathrm{L} \\
\times \mathrm{W} \times \mathrm{x} \mathrm{H})\end{array}$ & L. articulate & $(1)-(16)$ & Municipal & $86-90$ & [32] \\
\hline $\begin{array}{l}\text { HSF } \\
\text { VF }\end{array}$ & $\begin{array}{l}10 \text { pilot scale systems, total } \\
37.5 \mathrm{~m}^{2}\end{array}$ & Phragmites australis & $\begin{array}{l}(3)-(7),(9)- \\
(14),(16)\end{array}$ & Landfill leachate & 94 & [33] \\
\hline HSF & $\begin{array}{l}10 \text { pilot scale systems: } \\
50 \times 50 \times 0,6(\mathrm{~m})(\mathrm{L} \times \mathrm{W} \times \mathrm{H})\end{array}$ & Phragmites australis & $\begin{array}{l}(3)-(7),(9) \text { - } \\
(14),(16)\end{array}$ & Landfill leachate & 63 & [33] \\
\hline FWS & $\begin{array}{l}2 \text { pilot scale systems: } \\
\text { 160x75x70 }(\mathrm{cm})(\mathrm{LxWxH})\end{array}$ & Phragmites australis & (3), (12) & Municipal & $>80$ & [34] \\
\hline
\end{tabular}

The correspondence of the numbers with the PAHs is as follows: (a) (1) Acenaphthene, (2) Acenaphthylene, (3) Anthracene, (4) Benzo(a)anthracene, (5) Benzo(a) pyrene, (6) Benzo(b) fluoranthene, (7) Benzo(g,h,i) \perylene, (8) Benzo(k) \fluoranthene, (9) Chrysene, (10) Dibenzo(a,h)anthracene, (11) Phenanthrene, (12) Fluoranthene, (13) Fluorene, (14) Indeno(1,2,3-c,d)pyrene, (15) Naphthalene, (16) Pyrene.

FWS: Free Water Surface Flow; HSF: Horizontal Subsurface Flow; VF: Vertical Flow 


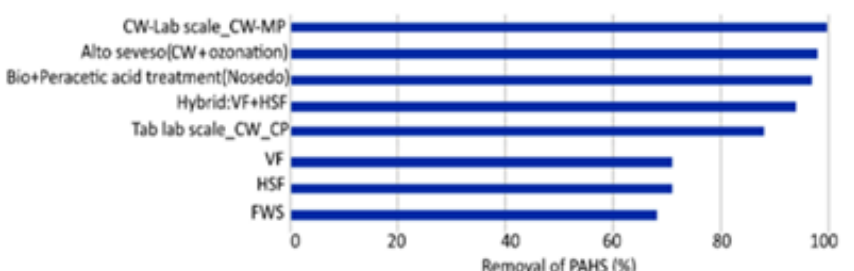

Figure 4: Comparative analysis of removal rates of PAHs with different CW systems.

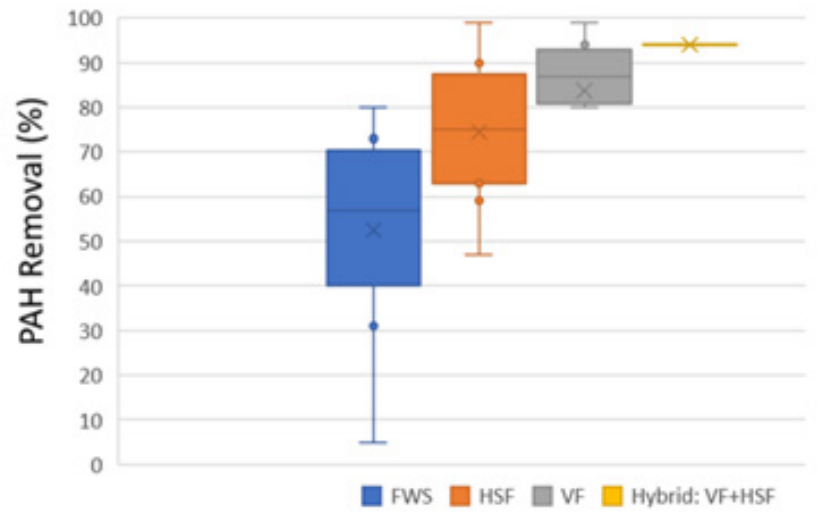

Figure 5: Removal efficiency of CW.

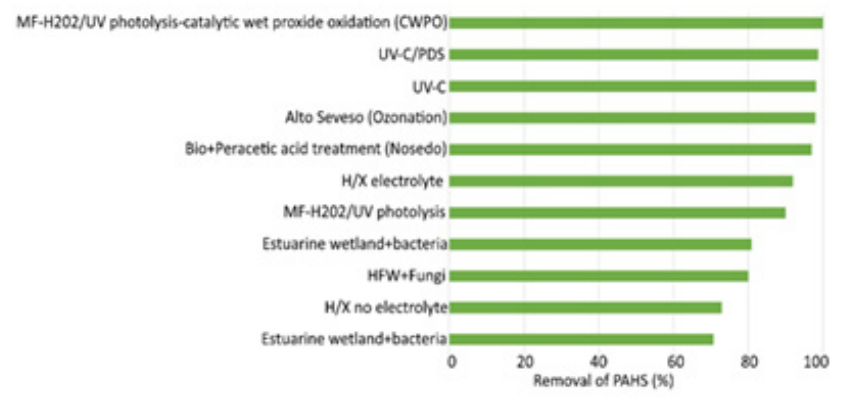

Figure 6: Comparative analysis of removal PAHs technologies.

\section{Conclusion}

In this article, the effectiveness of $\mathrm{CW}$ in the removal of PAHs from wastewater and various other removal processes were studied. The combination of the biological method with ozonation showcased promising results whereas, the oxidation-based methods (e.g., electrochemical oxidation) released ions into treated effluents that were harmful to animals and human health. Moreover, in various articles, the photodegradation method was one of the most efficient methods in the removal of PAHs but the overall construction and operating cost make it difficult to produce and maintain. Lastly, the efficiency of the microbiological treatment method was low and perhaps negligible compared to other PAHs removal methods.

In conclusion, as evident from above, the CW technology offers the optimal trade-off between cost and efficiency as: (a) the PAHs removal rate is high and, in most cases, greater than $80 \%$, (b) it uses natural materials for its construction, and (c) construction and operating cost is at reasonable levels, thus making it an affordable environmentally friendly solution.

\section{References}

1. European Commission. Commission Regulation (EC). (2011) 1881/2006 as regards maximum levels for polycyclic aromatic hydrocarbons in foodstuffs. Official Journal of the European Union. L215: 7-8.

2. Nagy AS, Simon G, Szabo J, Vass I (2013) Polycyclic aromatic hydrocarbons in surface water and bed sediments of the Hungarian upper section of the Danube River. Environ Monit Assess 185(6): 4619-4631.
3. Jalova V, Jarosova B, Blaha L, Giesy JP, Ocelka T, et al. (2013) Estrogen-, androgen- and aryl hydrocarbon receptor mediated activities in passive and composite samples from municipal waste and surface waters. Environ Int 59: 372-383.

4. Gikas GD, Sylaios GK, Tsihrintzis VA, Konstantinou IK, Albanis T, et al. (2020) Comparative evaluation of river chemical status based on WFD methodology and CCME water quality index. Science of the Total Environment 745: 140849 .

5. Witt G (1995) Polycyclic aromatic hydrocarbons in water and sediment of the Baltic Sea. Marine Pollution Bulletin 31: 237-248.

6. Schulz Bull DE, Petrick G, Bruhn R, Duinker JC (1998) Chlorobiphenyls (PCB) and PAHs in water masses of the northern North Atlantic. Marine Chemistry 61: 101-114.

7. Sarria Villa R, Ocampo Duque W, Páez M, Schuhmacher M (2016) Presence of PAHs in water and sediments of the Colombian Cauca River during heavy rain episodes, and implications for risk assessment. Sci Total Environ 540: 455-465.

8. Johnsen AR, Wick LY, Harms H (2005) Principles of microbial PAHs degradation in soil. Environ Pollut 133: 71-84.

9. Xia W, Du Z, Cui Q, Dong H, Wang F, et al. (2014) Biosurfactant produced by novel Pseudomonas sp. WJ6 with biodegradation of $n$-alkanes and polycyclic aromatic hydrocarbons. J Hazard Mater 276: 489-498.

10. Ukiwe LN, Egereonu UU, Njoku PC, Nwoko CI, Allinor JI (2013) Polycyclic aromatic hydrocarbons degradation techniques. International Journal of Chemistry 5: 43-55.

11. Centers for Disease Control and Prevention (CDC) (2021) Polycyclic aromatic hydrocarbons (PAHs) factsheet.

12. Luch A (2005) The carcinogenic effects of polycyclic aromatic hydrocarbons. World Scientific ISBN-13: 978-1860944178. ISBN-10: 1860944175.

13. Kadlec RH, Wallace SD (2009) Treatment wetlands. ( $2^{\text {nd }}$ edn). Taylor and Francis Group; UK.

14. Gikas GD, Tsihrintzis VA (2014) Municipal wastewater treatment using constructed wetlands. Water Utility Journal 8: 57-65.

15. Tararua District Council (2018) Woodville wastewater treatment plant Proposed wetland concept. Tonkin \& Taylor 1005792.0000.

16. Dotro G, Langergraber G, Molle P, Nivala J, Puigagut Juarez J, et al. (2017) Treatment wetlands. Biological Wastewater Treatment Series 7. IWA Publishing; UK.

17. Papaevangelou VA, Gikas GD, Vryzas Z, Tsihrintzis VA (2017). Treatment of agricultural equipment rinsing water containing a fungicide in pilot-scale horizontal subsurface flow constructed wetlands. Ecological Engineering 101: 193-200

18. Gikas GD, Perez Villanueva M, Tsioras M, Alexoudis C, Perez Rojas G, et al. (2018) Low-cost approaches for the removal of terbuthylazine from agricultural wastewater: Constructed wetlands and biopurification system. Chemical Engineering Journal 335: 647-656.

19. Gikas GD, Vryzas Z, Tsihrintzis VA (2018) S-metolachlor herbicide removal in pilot-scale horizontal subsurface flow constructed wetlands. Chemical Engineering Journal 339: 108-116.

20. Gikas GD, Tsihrintzis VA, Akratos CS (2011) Performance and modeling of a vertical flow constructed wetland-maturation pond system. Journal of Environmental Science and Health 4: 692-708.

21. Alsghayer R, Salmiaton A, Mohammad T, Idris A, Ishak CF (2020) Removal Efficiencies of Constructed Wetland Planted with Phragmites and Vetiver in Treating Synthetic Wastewater Contaminated with High Concentration of PAHs. Sustainability 12: 3357.

22. Fountoulakis MS, Terzakis S, Kalogerakis N, Manios T (2009) Removal of polycyclic aromatic hydrocarbons and linear alkylbenzene sulfonates from domestic wastewater in pilot constructed wetlands and a gravel filter. Ecological Engineering 35: 1702-1709.

23. Terzakis S, Fountoulakis MS, Georgaki I, Albantakis D, Sabathianakis I, et al. (2008) Constructed wetlands treating highway runoff in the central Mediterranean region. Chemosphere 72: 141-149. 
24. Guo Z, Kang Y, Hu Z, Liang S, Xie H, et al. (2020) Removal pathways of benzofluoranthene in a constructed wetland amended with metallic ions embedded carbon. Bioresource Technology 311: 123481.

25. Kang Y, Xie H, Li B, Zhang J, Hao Ngo H, et al. (2019) Performance of constructed wetlands and associated mechanisms of PAHs removal with mussels. Chemical Engineering Journal 357: 280-287.

26. Nas B, Argun ME, Dolu T, Ateş H, Yel E, et al. (2020) Occurrence, loadings and removal of EU-priority polycyclic aromatic hydrocarbons (PAHs) in wastewater and sludge by advanced biological treatment, stabilization pond and constructed wetland. J Environ Manage 268: 110580.

27. Shen X, Zhang J, Xie H, Hu Z, Liang S, et al. (2020) Intensive removal of PAHs in constructed wetland filled with copper biochar. Ecotoxicol Environ Saf 205: 111028.

28. Walaszek M, Bois P, Laurent J, Lenormand E, Wanko A (2018) Micropollutants removal and storage efficiencies in urban stormwater constructed wetland. Sci Total Environ 645: 854-864.

29. Pálfy TG, Gerodolle M, Gourdon R, Meyer D, Troesch S, et al. (2017) Performance assessment of a vertical flow constructed wetland treating unsettled combined sewer overflow. Water Sci Technol 75: 2586-2597.
30. Lamichhane BS (2017) Improve the efficiency of constructed wetlands in removing polycyclic aromatic hydrocarbons (PAHs) from stormwater. Department of Civil Engineering-Curtin University.

31. Leung JYS, Cai Q, Tam NFY (2016) Comparing subsurface flow constructed wetlands with mangrove plants and freshwater wetland plants for removing nutrients and toxic pollutants. Ecological Engineering 95: 129-137.

32. Al Sbani NH, Abdullah SRS, Idris M, Hasan HA, Jehawi OH, et al. (2016) Sub-surface flow system for PAHs removal in water using Lepironia articulate under greenhouse conditions. Ecological Engineering 87: 1-8.

33. Wojciechowska E (2013) Removal of persistent organic pollutants from landfill leachates treated in three constructed wetland systems. Water Sci Technol 68: 1164-1172.

34. Giraud F, Guiraud P, Kadri M, Blake G, Steiman R (2001) Biodegradation of anthracene and fluoranthene by fungi isolated from an experimental constructed wetland for wastewater treatment. Water Res 35: 4126-4136. 